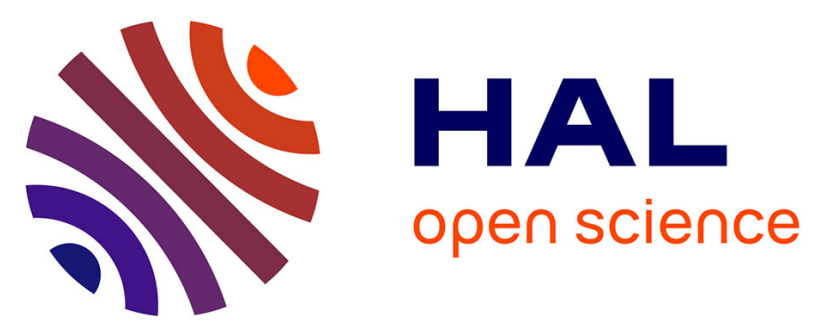

\title{
Ferrate(VI) based chemical oxidation for the remediation of aged PCB contaminated soil Comparison with conventional oxidants and study of limiting factors
}

\author{
O. Monfort, M. Usman, I. Soutrel, K. Hanna
}

\section{- To cite this version:}

O. Monfort, M. Usman, I. Soutrel, K. Hanna. Ferrate(VI) based chemical oxidation for the remediation of aged PCB contaminated soil Comparison with conventional oxidants and study of limiting factors. Chemical Engineering Journal, 2019, 355, pp.109-117. 10.1016/j.cej.2018.08.116 . hal-01905110

HAL Id: hal-01905110

https://hal-univ-rennes1.archives-ouvertes.fr/hal-01905110

Submitted on 7 Nov 2018

HAL is a multi-disciplinary open access archive for the deposit and dissemination of scientific research documents, whether they are published or not. The documents may come from teaching and research institutions in France or abroad, or from public or private research centers.
L'archive ouverte pluridisciplinaire HAL, est destinée au dépôt et à la diffusion de documents scientifiques de niveau recherche, publiés ou non, émanant des établissements d'enseignement et de recherche français ou étrangers, des laboratoires publics ou privés. 


\section{Ferrate(VI) based chemical oxidation for the remediation of aged PCB contaminated soil:}

\section{Comparison with conventional oxidants and study of limiting factors}

Olivier Monfort ${ }^{a,{ }^{*}}$, Muhammad Usman ${ }^{\mathrm{b}, \mathrm{c}}$, Isabelle Soutrel ${ }^{\mathrm{a}}$, Khalil Hanna ${ }^{\mathrm{a},{ }^{*}}$

${ }^{a}$ Univ Rennes, Ecole Nationale Supérieure de Chimie de Rennes, CNRS, ISCR (Institut des

Sciences Chimiques de Rennes) - UMR 6226, F-35000 Rennes, France

${ }^{b}$ Environmental Mineralogy, Center for Applied Geosciences, University of Tübingen, 72074

Tübingen, Germany

${ }^{\mathrm{c}}$ Institute of Soil and Environmental Sciences, University of Agriculture, Faisalabad 38040,

Pakistan

"correspondence: olivier.monfort@ensc-rennes.fr and khalil.hanna@ensc-rennes.fr ;

ENSCR, 11 allée de Beaulieu, CS 50837, 35708 Rennes Cédex 7, France

\section{Abstract}

Ferrate $(\mathrm{Fe}(\mathrm{VI}))$ has emerged as an efficient oxidant to treat organic pollutants in aqueous solution. However, its application has never been assessed to remediate the contaminated soils. Here, we report the first study to use $\mathrm{Fe}(\mathrm{VI})$ for chemical oxidation of PCBs in historically contaminated soils obtained from an industrial wasteland. The first part of this study explores the efficiency of ferrate(VI) to degrade PCBs under various experimental conditions (liquid/solid ratio, oxidant dose, temperature and reaction time). Integrated application of $\mathrm{Fe}(\mathrm{VI})$ with conventional oxidants (hydrogen peroxide $\mathrm{H}_{2} \mathrm{O}_{2}$, persulfate $\mathrm{S}_{2} \mathrm{O}_{8}{ }^{2-}$ and peroxymonosulfate $\mathrm{HSO}_{5}{ }^{-}$) was also tested. Conventional oxidants resulted in only 2 - 
$12 \%$ PCB degradation while $\mathrm{Fe}(\mathrm{VI})$ removed $30 \%$ of $\mathrm{PCBs}$. Integrated use of $\mathrm{Fe}(\mathrm{VI})$ and conventional oxidants improved the degradation efficiency which was the highest $(40 \%$ removal) by $\mathrm{Fe}(\mathrm{VI}) / \mathrm{HSO}_{5}{ }^{-}$. This could be attributed to two-step degradation proceeding firstly by electron transfer with $\mathrm{Fe}(\mathrm{VI})$ followed by radical attack of conventional oxidants. To evaluate if PCB degradation is limited by soil factors, role of carbonate content, overall soil matrix, and PCB availability were assessed as a second part of this study. Negative role of soil matrix was highly prominent for conventional oxidants than Fe(VI). An increase in PCB availability improved the treatment efficiency (45\% removal by Fe(VI) alone) highlighting the role of soil factors. All these results indicate the higher suitability and efficiency of Fe(VI) as compared to the conventional oxidants for soil remediation. Since use of $\mathrm{Fe}(\mathrm{VI})$ is innovative for both soil remediation and PCB oxidation, degradation mechanisms are also proposed.

Keywords: PCB contamination; Ferrate(VI); Soil remediation; Chemical oxidation; Peroxymonosulfate. 


\section{Introduction}

Polychlorinated biphenyls (PCBs) are a group of 209 different congeners that are persistent organic pollutants with well-known toxicity and carcinogenic effects [1-3]. Owing to their hydrophobic nature, PCBs are strongly partitioned and bio-accumulated in soils, especially those rich in organic matter [1-4]. Their adverse effects have led the European Commission to heavily restrict their use in 1985 [4], however, PCBs still represent a global problem due to their strong environmental persistence (high chemical stability of $\mathrm{C}-\mathrm{Cl}$ bond). Therefore, search for efficient treatment technologies for PCBs is a major environmental challenge especially in contaminated soils where remediation is a complicated task [1-4]. Indeed, the fate of PCBs depends on the components of the contaminated matrix where PCBs are associated [3-5]. However, very limited data is available about the effects of various soil factors on the fate of PCBs [4].

Among existing treatments to remove $\mathrm{PCBs}$, chemical oxidation treatments are showing great potential as a viable remediation technology $[3,7]$. Chemical oxidation is widely used to treat pollutants in ground and surface water [5-7] and thus can be potentially used to treat subsurface zone (e.g. vadose zone). Traditionally, chemical oxidation involves the use of oxidants such as persulfate $\left(\mathrm{S}_{2} \mathrm{O}_{8}{ }^{2-}\right)$, hydrogen peroxide $\left(\mathrm{H}_{2} \mathrm{O}_{2}\right)$ or permanganate $\left(\mathrm{MnO}_{4}{ }^{-}\right)$to degrade organic pollutants in contaminated soils $[3,4]$. These oxidants can be activated using heat or a transition metal in order to produce highly oxidative radicals $[4,8]$. For example, $\mathrm{S}_{2} \mathrm{O}_{8}{ }^{2-}$ and $\mathrm{H}_{2} \mathrm{O}_{2}$ can be activated to produce $\mathrm{SO}_{4}{ }^{--}\left(\mathrm{E}^{\circ}=2.6 \mathrm{~V}\right)$ and $\mathrm{HO}^{\circ}\left(\mathrm{E}^{\circ}=2.8\right.$ V) radicals which are strong oxidants than the original species. However, chemical oxidationbased treatments exhibit contrasting remediation outcomes in aged contaminated soils 
since the characteristics and buffering capacity of the soil have strong impacts on the removal of pollutants [4].

Recently, a novel remediation strategy based on the use of ferrate( $\mathrm{VI})\left(\mathrm{FeO}_{4}{ }^{2-}\right.$ or $\mathrm{Fe}(\mathrm{VI}))$ has been developed [9-13]. High-valent iron species such as $\mathrm{Fe}(\mathrm{VI})$ can carry out radical and electron transfer reactions [14]. $\mathrm{Fe}(\mathrm{VI})$ is a powerful oxidant with strong efficiency over a wide $\mathrm{pH}$ range $\left(E^{\circ}=2.2\right.$ and $0.7 \mathrm{~V}$ in acidic and basic media, respectively) $[7,9,11,15-18]$. Ferrate(VI) can exist in four forms according to the $\mathrm{pH}$ as shown in equation 1 $[9,10,16,17]$

$$
\begin{aligned}
& \mathrm{H}_{3} \mathrm{FeO}_{4}{ }^{+}=\mathrm{H}_{2} \mathrm{FeO}_{4}=\mathrm{HFeO}_{4}{ }^{-}=\mathrm{FeO}_{4}{ }^{2-} \quad p K a_{1}=1.6 ; p K a_{2}=3.5 ; p K a_{3}=7.3 \\
& 4 \mathrm{FeO}_{4}{ }^{2-}+10 \mathrm{H}_{2} \mathrm{O}=4 \mathrm{Fe}(\mathrm{OH})_{3}+3 \mathrm{O}_{2}+8 \mathrm{OH}^{-}
\end{aligned}
$$

Although ferrate(VI) is more stable at alkaline $\mathrm{pH}$, it exhibits stronger oxidation efficiency at acidic and circumneutral $\mathrm{pH}$ where the most reactive form, monoprotonated ferrate $\left(\mathrm{HFeO}_{4}{ }^{-}\right.$ ), is present $[14,18,20]$. Moreover, $\mathrm{HFeO}_{4}{ }^{-}$is readily decomposed to $\mathrm{Fe}(\mathrm{V})$ and $\mathrm{Fe}(\mathrm{IV})$ species that are more reactive than $\mathrm{Fe}(\mathrm{VI})$ for oxidation process $[11,18]$. It is generally known that the ferrates species (Fe +IV to $+\mathrm{VI}$ ) preferentially target pollutants with electron rich moieties such as phenols, anilines, amines, aromatics, alcohols and olefins in water $[14,19,21,27]$. However, its use has rarely been reported for soil remediation as correctly identified in a very recent review article [10]. Moreover to the best of our knowledge, the use of Fe(VI) for oxidative degradation of polychlorinated compounds such as PCBs has been reported neither in aqueous medium nor in soil. In addition to its high oxidation efficiency, degradation products of ferrate(VI) are non-toxic e.g. Fe(III) (hydr)oxides, and may preserve the biodiversity of the treated soil $[9,11-13]$. Therefore, ferrate(VI) can be considered as a 
pioneering green oxidant that could be used for in-situ chemical oxidation of contaminated soils.

Present study is the first to address the use of ferrate(VI) for oxidative degradation of PCBs in an aged contaminated soil originated from an industrial wasteland. Main objectives of this study were: (1) to assess the PCB removal efficiency by Ferrate(VI), alone and/or in combination with different oxidants (including $\mathrm{S}_{2} \mathrm{O}_{8}{ }^{2-}$ and $\mathrm{HSO}_{5}{ }^{-}$) and (2) to address the limiting factors affecting oxidation efficiency. To achieve the first objective, ferrate(VI) efficiency was tested under various experimental conditions (liquid/solid ratio L/S, oxidant dose, temperature and reaction time). Studying the effect of water content is essential to choose a suitable L/S ratio for upscaling of experiments. Integrated application of ferrate(VI) and conventional oxidants was also tested to improve the oxidation efficiency as they proceed through different oxidation mechanisms including electron transfer (ferrate(VI)) and radical pathways (conventional oxidants). Coupling of different oxidation pathways could be advantageous for an efficient pollutant removal. Remediation efficiency is usually limited by soil matrix effect and pollutant availability which was investigated as a second part of this study with a focus on carbonate content, overall soil matrix and PCB availability. Since this is the first study reporting the use of ferrate(VI) for soil remediation, oxidation mechanisms in soil are also proposed.

\section{Experimental section}

\subsection{Chemicals}


Solution of 6 indicator-PCBs for European zone were purchased from Sigma-Aldrich and contained 6 congeners (PCB28, PCB52, PCB101, PCB138, PCB153, PCB180) while supplementary solution of 17 congeners (PCB33, PCB53, PCB77, PCB81, PCB105, PCB110, PCB114, PCB118, PCB123, PCB126, PCB149, РCB156, PCB157, PCB167, PCB169, PCB170, PCB189) were purchased from TechLab (France). In addition, PCB209 (analytical standard) in solid form was purchased from Sigma-Aldrich and was used without further purification. Potassium ferrate (20\%) was supplied by Nanolron company (Czechia). Hydrogen peroxide $\left(\mathrm{H}_{2} \mathrm{O}_{2}\right) 50$ wt\%, oxone ${ }^{\circledR}\left(\mathrm{KHSO}_{5}\right)$, iron(II) sulfate heptahydrate (>99\%) and methyl-betacyclodextrin were purchased from Sigma-Aldrich. Potassium persulfate $\left(\mathrm{K}_{2} \mathrm{~S}_{2} \mathrm{O}_{8}\right)$ was supplied by Merck. Hydrochloric acid (37\%) and $n$-hexane (95\% for pesticide residue analysis) were purchased from Acros Organics. Fontainebleau sand, with a grain size range of 150-300 $\mu \mathrm{m}$, was obtained from Prolabo (France).

\subsection{Soil characteristics}

The soil, which was provided by the French Environment and Energy Management Agency (ADEME), was dried, crushed and passed through $500 \mu \mathrm{m}$ sieve for further remediation experiments. The main characteristics of the soil are summarized in Table 1 . The soil contained high amount of carbonate (almost $30 w t \% \mathrm{CaCO}_{3}$ ) which results in high $\mathrm{pH}$ in water (9.93). The soil contains approximatively 2 wt\% of soil organic matter (SOM) and trace amount of metals.

The PCB concentrations in the soil samples were determined by Gas Chromatography-Mass Spectrometry (GC-MS) and results are summarized in Table 2. The total amount in PCBs in the soil is very high and above the threshold values established in most of the countries [1]. Total content of the main PCBs is $>1000 \mathrm{mg} / \mathrm{Kg}$ out of which $>50 \%$ 
is composed of hexachlorinated biphenyls while penta- and hepta-chlorinated biphenyls represent approximatively $45 \%$ of the total amount.

\subsection{Oxidation experiments}

A summary of different experiments performed in this study is presented in Table 3. Firstly, experiments were performed at different liquid-to-solid ratios (L/S) of 1, 5, 10 and 15 to evaluate the impact of $\mathrm{L} / \mathrm{S}$ ratio on oxidation efficiency of $\mathrm{Fe}(\mathrm{VI})$. In a typical experiment, 2 $\mathrm{g}$ of soil was first homogenized with $1 \mathrm{~g}$ of solid potassium ferrate (loading of $0.5 \mathrm{~g} / \mathrm{g}$ ). Then, the treatment was started by adding suitable amount of deionized water to obtain the desired L/S ratio while stirring $(800 \mathrm{rpm})$ at room temperature. All experiments were performed in triplicates and blank sample is referred to be the untreated soil. Further experiments were performed with different amounts of ferrate applied as a single dose or in sequential additions at different time intervals. Such tests aimed to improve the chemical oxidation of PCBs since it usually increases with the $\mathrm{Fe}(\mathrm{VI})$ dose $[6,7,10,23]$. Moreover, sequential addition may prevent possible non-productive decomposition pathways of oxidant that generally occurs at very high oxidant concentration. An additional test was also performed at $4{ }^{\circ} \mathrm{C}$ since temperature increased during the oxidative process due to the exothermic nature of ferrate(VI) decomposition into Fe(III) [9].

Then, the efficiency of ferrate(VI) was compared to that of conventional oxidants including peroxymonosulfate $\left(\mathrm{HSO}_{5}{ }^{-}\right)$, persulfate $\left(\mathrm{S}_{2} \mathrm{O}_{8}{ }^{2-}\right)$ and hydrogen peroxide $\left(\mathrm{H}_{2} \mathrm{O}_{2}\right)$ applied at different oxidant doses (Table 3). $\mathrm{H}_{2} \mathrm{O}_{2}$ was applied with or without $\mathrm{Fe}$ (II) to test the effect of iron activation on oxidation efficiency. These conventional oxidants were chosen because of their ability to form oxidative radicals such as $\mathrm{SO}_{4}{ }^{\circ-}$ and $\mathrm{HO}^{\circ}$. In addition, potential antagonist and synergistic effect was studied by combining ferrate(VI) with 
conventional oxidants including $\mathrm{HSO}_{5}{ }^{-}$and $\mathrm{S}_{2} \mathrm{O}_{8}{ }^{2-}$ at different concentrations (Table 3). In this case, instead of adding deionized water to ferrate(VI), a solution of oxidant at desired concentration was added to the mixture.

Further experiments were performed to evaluate the impact of factors associated to soil matrix as well as the PCBs availability. This is crucial for evaluating the limiting factors in PCBs removal in the tested soil and by extrapolation, it could provide important data on the type of soil that could be effectively treated using ferrate(VI) oxidation. Concerning the soil matrix, the effect of carbonate is mainly studied. For this, the soil was decarbonated by fumigation using $7 \mathrm{M} \mathrm{HCl}$ and the resulting $\mathrm{pH}$ in water reached 4.94 . The mass loss corresponded to the amount of carbonates in the original soil (Table 1). Subsequently, different oxidation treatments were applied to $2 \mathrm{~g}$ of decarbonated soil, as summarized in Table 3, by comparing and combining ferrate(VI) and conventional oxidants. On the other hand, to evaluate the impact of PCB availability, different procedures were opted (Table 3) which have already shown positive impacts in previous studies on pollutant availability for ultimately a better remediation [5,30]. For this purpose, soil was subjected to different pretreatments including the use of complexing agent, the methyl- $\beta$-cyclodextrin, and the exposition of the soil to $40^{\circ} \mathrm{C}$. In these cases, the mixture was stirred for $24 \mathrm{~h}$ before the addition of ferrate(VI).

To further assess the impact of soil matrix, extractable organic matter (EOM) was separated from soil by following the extraction procedure detailed in section 2.4 and was spiked on sand (Table 3). Purpose is to separate the extractable organic matter (EOM) from the mineral and insoluble organic matter (IOM). In next step, to further study the impact of PCB availability, the soil extract was not separated from the soil, rather it was evaporated to 
to spike on the same soil from which it was extracted. In this case, purpose is to freshly contaminate the original matrix since recalcitrance could differ from historically contaminated soil (Table 3). Spiking process was completed after full evaporation of hexane solvent.

\subsection{PCB extraction and analysis}

Prior to extraction, the treated soil (or sand) samples were freeze-dried using Labconco Freezone 2.5 to remove water while avoiding the PCBs volatilization. Freeze-dried samples were subjected to extraction using Dionex ASE 300. Extraction was carried out with 3 cycles in hexane as solvent at $135^{\circ} \mathrm{C}$ and 1500 psi. The extract was then concentrated by rotary evaporation (Buchi Rotavapor $R$-200) to approximatively $7 \mathrm{~mL}$ which was further filtered through a PTFE $0.2 \mu \mathrm{m}$ syringe filter. Obtained extract was then reduced to $5 \mathrm{~mL}$ using nitrogen stream in warm water bath (N-EVAP 111). Then, internal standard (15 $\mu \mathrm{L}$ of 1 g/L PCB209) was added to a glass vial and homogenized with $1500 \mu \mathrm{L}$ of sample solution for analysis [1].

PCBs were then quantified by GC-MS (Perkin Elmer, Clarus 500) using splitless mode and injection volume of $2 \mu \mathrm{L}$. The GC-MS analysis was performed on DB5-MS column ( $\mathrm{L}=60$ $\mathrm{m} ; \varnothing=0.25 \mathrm{~mm}$; film thickness $=0.25 \mu \mathrm{m}$ ) and He was used as gas carrier with a flow rate of $1 \mathrm{~mL} / \mathrm{min}$. The analytical program was started with vaporization of the sample at $350{ }^{\circ} \mathrm{C}$ followed by a hold at $140{ }^{\circ} \mathrm{C}$. Subsequently, two temperature gradients from 140 to $200{ }^{\circ} \mathrm{C}$ $\left(20{ }^{\circ} \mathrm{C} / \mathrm{min}\right)$ and from 200 to $320^{\circ} \mathrm{C}\left(3{ }^{\circ} \mathrm{C} / \mathrm{min}\right)$ were applied with a final hold for $4 \mathrm{~min}$ before a cool down process. The PCBs was identified based on their $m / z$ value and their retention time compared to authentic standard (PCB209). The Table S1 (in Supplementary Material) summarized all the identified PCBs with their associated retention times. 


\section{Results and discussion}

Firstly, oxidation experiments with $\mathrm{Fe}(\mathrm{VI})$ were performed using different $\mathrm{L} / \mathrm{S}$ ratio (from 1 to 15 ) to study its impact on Fe(VI) efficiency and to identify a suitable L/S ratio. The results in Fig. S1 (Supplementary Material) showed that the water content in the soil has negligible effect on the extent of $P C B$ removal. Therefore, we chose $L / S=1$ for further experiments reported in the present study which is a realistic choice for potential upscaling to in situ applications. It should be noted that lower ratios (i.e. L/S ratio $<1$ ) were not tested here, because that does not allow uniform mixing/contact of the soil with the oxidant solution due to the lower water contents. It is also worth noting that many studies were devoted to pollutant removal in soil suspension at $L / S>1[5,10,33,34]$, such high ratio being less relevance for in-situ applications [2]. In addition, a treatment time of $24 \mathrm{~h}$ is chosen for further experiments on the basis of a preliminary kinetic study performed until 48 h (data not shown). Indeed, it was observed that no further pollutant degradation occurred beyond $24 \mathrm{~h}$ for any of the chemical oxidation system tested in this work. To our knowledge, no data about the use of $\mathrm{Fe}(\mathrm{VI})$ is available in soil remediation, which makes it difficult to fairly compare our data with the literature.

\subsection{PCB removal using different oxidation treatments}

\subsubsection{Ferrate(VI) oxidation}

Removal extent of different PCB congeners in tested soil by $\mathrm{Fe}(\mathrm{VI})$ treatment is presented in Fig. 1. Heavy (high chlorinated) PCBs were found to be the most degraded group of PCBs. Degradation extent of the hepta-chlorinated biphenyl congeners 170 and 180 
was approximately $50 \%$ as compared to the $30 \%$ degradation of the remaining lower chlorinated PCBs (Fig. 1B). This could be explained by the fact that heavy PCBs such as heptaCB are degraded to lower chlorinated PCBs [1] and thus, the decrease in overall concentration of light PCBs appears relatively lower (i.e. the observed decrease in light PCBs does not reflect their real degradation since heavy PCBs are degraded to lighter ones).

In order to improve the removal efficiency of PCBs in tested soil, different doses of $\mathrm{Fe}(\mathrm{VI})$ were introduced in single and sequential addition at different time intervals (Fig. S2). It was observed that neither the dose of ferrate(VI) nor the sequential addition affects significantly the PCBs degradation. The usual trend of higher oxidation efficiency of $\mathrm{Fe}(\mathrm{VI})$ at higher oxidant dose $[6,7,10,23]$ was not observed in our case that might be attributed to the strong refractory nature of PCBs or their unavailability for further remediation as observed for highly sequestered pollutants [5]. As Fe(VI) dose was not a limiting factor, the minimum dose $(0.5 \mathrm{~g} / \mathrm{g})$ was found as the optimal loading for our experimental conditions. Therefore, this dose was chosen for further experiments. Because of the degradation of ferrate $(\mathrm{VI})$ in presence of water is exothermic [9], a test was also carried out at $4^{\circ} \mathrm{C}$ instead of room temperature but only a slight increase in PCBs degradation efficiency (+4\%) was achieved (Fig. S3).

\subsubsection{Ferrate(VI) vs. conventional oxidants}

The oxidation efficiency of ferrate( $\mathrm{VI})$ was compared to that of conventional oxidants including $\mathrm{S}_{2} \mathrm{O}_{8}{ }^{2-}, \mathrm{HSO}_{5}{ }^{-}$and $\mathrm{H}_{2} \mathrm{O}_{2}$ to remove PCBs in the tested soil (Fig. 2). Obtained results indicated the following efficiency order: $\mathrm{Fe}(\mathrm{VI})\left(30 \% \mathrm{PCB}\right.$ removal) $>\mathrm{HSO}_{5}{ }^{-}(12 \%$ removal) $>$ $\mathrm{S}_{2} \mathrm{O}_{8}{ }^{2-}$ (8\% removal) $>\mathrm{H}_{2} \mathrm{O}_{2}$ (2\% removal). Application of $\mathrm{Fe}(\mathrm{II})$-activated $\mathrm{H}_{2} \mathrm{O}_{2}$ resulted in almost similar oxidation efficiency $(3 \%)$ to that of $\mathrm{H}_{2} \mathrm{O}_{2}$ alone which could be correlated to 
the precipitation of $\mathrm{Fe}(\mathrm{II})$ due to the higher $\mathrm{pH}(9.93)$ in tested soil. Conventional oxidants usually degrade pollutants through radical mechanism e.g. hydroxyl radicals attack organic structure usually through hydroxylation [6]. However in case of PCBs, such mechanism is not favored probably due to the high degree of chlorination of molecules hindering the access to the carbon aromatic structure [1], thus necessitating a dechlorination step [33] which is hardly achieved using radical pathway. Qin et al. also demonstrated that light PCB (PCB28) needs to be dechlorinated before being mineralized [32], supporting the above suggested mechanistic pathway. This difficulty in oxidizing PCBs by radicals is supported by the inefficacy of Fe(II)-activated $\mathrm{H}_{2} \mathrm{O}_{2}$ treatment, which involves the activation of $\mathrm{H}_{2} \mathrm{O}_{2}$ (Fig. 2). In addition, the $\mathrm{pH}$ of the soil, which is 9.93 , limits the formation of hydroxyls radicals.

On the other hand, $\mathrm{Fe}(\mathrm{VI})$ preferentially attacks electron-rich moieties and acts via mechanisms based on electron transfer as illustrated in equations 3 and 4 ( $R$ represents an organic compound) $[6,18,20,21,27]$. Attempts to identify the reaction by-products using GCMS and then elucidate the Fe(VI) oxidation mechanism failed, probably due to the low PCB degradation extent and the complex organic contamination in the investigated soil. Furthermore, oxidation products of heavier PCBs are supposed to be lighter PCBs, which are originally present in the investigated soil, as reported in previous work [1]. To fill this knowledge, we used the most relevant published data on how $\mathrm{Fe}(\mathrm{VI})$ reacts with organic compounds. Indeed, a plausible reaction step may involve transfer of two electrons accompanied by oxygen atom transfer, leading to dechlorinated by-products $[6,27]$. Other degradation steps may imply oxidation by $\mathrm{Fe}(\mathrm{VI})$ but also by $\mathrm{Fe}(\mathrm{V})$ and $\mathrm{Fe}(\mathrm{IV})$ (i.e. species from Fe(VI) decomposition) [27].

$$
\mathrm{Fe}^{\mathrm{VI}} \mathrm{O}_{4}{ }^{2-}+R \quad \rightarrow \mathrm{Fe}^{\mathrm{IV}} \mathrm{O}_{3}{ }^{2-}+\mathrm{R}(\mathrm{O})
$$




$$
\mathrm{Fe}^{\mathrm{Vl}} \mathrm{O}_{4}{ }^{2-}+R \quad \rightarrow \mathrm{Fe}^{\mathrm{V}} \mathrm{O}_{4}{ }^{3-}+\mathrm{R}^{\cdot+}
$$

As the action of ferrate depends strongly on the reaction $\mathrm{pH}$, alkaline nature of tested soil $(\mathrm{pH}$ 9.93) could result in lower efficiency of $\mathrm{Fe}(\mathrm{VI})$ [27]. However, at alkaline $\mathrm{pH},+\mathrm{V}$ valent states of ferrate including monoprotonated and deprotonated $\mathrm{HFeO}_{4}{ }^{2-}$ and $\mathrm{FeO}_{4}{ }^{3-}$, respectively, co-exist simultaneously (eq. 5) [24,27]. Therefore, Fe(V) can be considered as one of the main oxidant for PCB degradation at alkaline $\mathrm{pH}$ [27].

$$
\mathrm{HFe}^{V} \mathrm{O}_{4}{ }^{2-} \stackrel{p K a=10.1}{\longleftrightarrow} \mathrm{Fe}^{V} \mathrm{O}_{4}{ }^{3-}
$$

\subsubsection{Integrated application of $\mathrm{Fe}(\mathrm{VI})$ and conventional oxidants}

After reaction, $\mathrm{Fe}(\mathrm{VI})$ is usually transformed into ferric (hydr)oxides in soil [10] which could be advantageous for its integrated application because iron minerals may activate conventional oxidants to produce stronger radicals at wide range of $\mathrm{pH}$ values [31]. Therefore, combined application of ferrate and conventional oxidants $\left(\mathrm{S}_{2} \mathrm{O}_{8}{ }^{2-}\right.$ and $\left.\mathrm{HSO}_{5}{ }^{-}\right)$at different concentrations was tested (Fig. 2, S4 and S5). At lower concentrations (2 and 20 $\mathrm{mM}$ ), no significant effect was observed for $\mathrm{HSO}_{5}{ }^{-}$(Fig. S4) while an antagonistic effect was noted for $\mathrm{S}_{2} \mathrm{O}_{8}{ }^{2-}$ (Fig. S5). However, at higher concentrations $(0.2 \mathrm{M})$, a positive effect of combined application of ferrate(VI) and these conventional oxidants was observed, especially for ferrate(VI)/ $\mathrm{HSO}_{5}{ }^{-}$system which removed $40 \%$ of PCBs. Similarly, integrated application of $\mathrm{Fe}(\mathrm{VI})$ with sulfur(IV) compounds such as sulfites resulted in better efficiency $[22,36]$. Indeed, combined Fe(VI)-S(IV) systems can generate various oxidative species, such as $\mathrm{Fe}(\mathrm{V})$ and $\mathrm{SO}_{5}{ }^{\circ-}$ in the present case, that could efficiently remove pollutants $[22,36]$.

The above observations explain the synergy using combined $\mathrm{Fe}(\mathrm{VI}) / \mathrm{S}_{2} \mathrm{O}_{8}{ }^{2-}$ and $\mathrm{Fe}(\mathrm{VI}) / \mathrm{HSO}_{5}{ }^{-}$treatments for $\mathrm{PCB}$ removal. Indeed, in the case of $\mathrm{Fe}(\mathrm{VI}) / \mathrm{HSO}_{5}{ }^{-}$, it is known 
that presence of ferrate $(\mathrm{VI})$ and $\mathrm{HSO}_{5}{ }^{-}$together exhibited a synergistic effect on oxidation efficiency [6]. Thus, the following oxidation mechanism can be proposed for the degradation of PCBs: (1) attack of the Fe(VI) on $\mathrm{e}^{-}$-rich chlorine substituent, and (2) Fe(VI) can still oxidize aromatic rings through $\mathrm{e}^{-}$and $\mathrm{O}$ atom transfer. The latter step is favored by the formation of radical species which can attack aromatics (leading potentially to aromatic ring opening) [6]. Although conventional oxidation processes can dechlorinate PCBs [32,33], the use of Fe(II) activated $\mathrm{H}_{2} \mathrm{O}_{2}$ system resulted in negligible degradation in our experimental conditions (Fig. 2 and $\mathrm{S6}$ ), suggesting that the attack of ferrate( $\mathrm{VI})$ on $\mathrm{Cl}$ substituents is more efficient than the action of the other oxidants. Therefore, the step involving ferrate(VI) is really necessary for synergistic action with radical oxidation of the chlorinated compounds.

\subsection{Effect of soil matrix and PCB availability on ferrate(VI) oxidation efficiency}

It is generally known that the oxidation efficiency can be limited by pollutant unavailability and/or soil matrix effect $[25,26,30]$. In tested soil, incomplete PCB degradation was observed irrespective of the ferrate $(\mathrm{VI})$ concentration and the nature of oxidation treatment. To understand whether it could be correlated to above limiting factors in tested soil, further experiments were performed to assess their role in $\mathrm{Fe}(\mathrm{VI})$ efficiency which are discussed in the following sections.

\subsubsection{Effect of soil matrix}

Effect of soil matrix was evaluated by studying the impact of carbonates and overall soil matrix. It is generally admitted that carbonates content negatively affect the efficiency of chemical oxidation $[28,29]$. To understand its role in the tested soil, decarbonatation of the soil was performed (since $\mathrm{CaCO}_{3}$ is the main component as seen in Table 1 ) through fumigation using concentrated $\mathrm{HCl}$ (eq. 6). Since carbonate represents $30 w t \%$ of the soil, 
total elimination of carbonates increased the initial concentration of PCBs per gram of dry decarbonated soil (Fig. S7).

$$
\mathrm{CaCO}_{3}+2 \mathrm{HCl} \rightarrow \mathrm{H}_{2} \mathrm{CO}_{3}+\mathrm{CaCl}_{2} \rightarrow \mathrm{CO}_{2}+\mathrm{H}_{2} \mathrm{O}+\mathrm{CaCl}_{2}
$$

The treatment of decarbonated soil by ferrate indicated higher PCB removal (45\%) as compared to that in raw soil (30\%) (Fig. 4) since decarbonatation also reduced the soil pH to 5. At this $\mathrm{pH}$, main form of ferrate(VI) is the monoprotonated species $\mathrm{HFeO}_{4}{ }^{-}$, the most reactive form, leading to higher oxidation than raw soil (Fig. 4A). Moreover, Fe(VI) oxidant degrades almost $60 \%$ of heavy PCBs such as hepta-CB (Fig. $4 B$ ). In addition, carbonate ions affect directly the stability of $\mathrm{Fe}(\mathrm{VI})$ [35]. Indeed, Kolar et al. have demonstrated that carbonates favor the decay of $\mathrm{Fe}(\mathrm{VI})$ and formation of iron(III) oxide/hydroxide particles, [35], thus supporting the better PCBs removal observed in decarbonated soil. On the other hand, elimination of carbonates did not improve the oxidation efficiency of conventional oxidants, compared to raw soil (Fig. 2), as they resulted in very poor PCB degradation in decarbonated (Fig. 5).

Combined treatments with ferrate( $\mathrm{VI})$ and conventional oxidants are also performed on decarbonated soil in order to compare with the efficiency of such treatments in raw soil, and thus to assess effects of carbonates content. In decarbonated soil (Fig. 5), the combined approach is less efficient than in raw soil suggesting a loss of synergy between $\mathrm{e}^{-}$transfer and radical pathway. This discrepancy in oxidation efficiency could be due to (1) increased concentration of PCBs in decarbonated soil (Fig. S7) and (2) possible interferences between radical and $\mathrm{e}^{-}$transfer mechanisms resulting from the $\mathrm{pH}$ decrease. On the other hand, the carbonate, also known as radical scavenger, has no effect on the removal of PCBs by 
$\mathrm{Fe}(\mathrm{II}) / \mathrm{H}_{2} \mathrm{O}_{2}$ (absence of ferrate), further confirming that $\mathrm{PCBs}$ are mainly degraded through $\mathrm{e}^{-}$ transfer in this soil.

In next step, effect of overall soil matrix was evaluated by extracting the organic extract (EOM) and spiking on sand. Then, the spiked sand was also subjected to chemical oxidation to assess the ability of ferrate(VI) to degrade PCBs in absence of soil matrix effect. PCB concentration in spiked sand was comparable to that of the initial soil. Obtained results indicated that degradation efficiency of PCBs is better in spiked sand ( $55 \%$ removal) than in raw soil ( $30 \%$ removal). Similar to the raw soil, degradation extent of heavy PCBs reached 50\% (Fig. 3A). However light PCBs (especially congeners 28 and 33) are almost fully degraded in spiked sand, probably because of high reactivity of ferrate(VI) with more accessible aromatic rings of the dehalogenated compounds.

The soil matrix plays a fundamental role in the degradation efficiency of PCBs. Indeed, soil and sand matrices are completely different since the soil is a more complex matrix which negatively affects the oxidation process due to the non-target consumption of oxidants. Application of ferrate $(\mathrm{VI})$ and $\mathrm{HSO}_{5}{ }^{-}$(alone or in combination) was also evaluated in spiked sand to provide more insights on the effect of matrix (Fig. 3B). $\mathrm{HSO}_{5}{ }^{-}$was chosen because of its higher efficiency with ferrate(VI) than other conventional oxidants used in raw soil (section 3.1.3). A similar degradation extent (45\%) of total PCBs was observed by ferrate(VI), $\mathrm{HSO}_{5}{ }^{-}$or $\mathrm{Fe}(\mathrm{VI}) / \mathrm{HSO}_{5}{ }^{-}$in spiked sand (Fig. 3B). Similar results (45\%) were also obtained for $\mathrm{Fe}(\mathrm{II}) / \mathrm{H}_{2} \mathrm{O}_{2}$ system highlighting that there is no effect of the nature of treatment on the PCBs removal in spiked sand. Considering the difference of PCB degradation in sand $(45 \%$ by all oxidants) and soil medium ( $30 \%$ by $\mathrm{Fe}(\mathrm{VI})$ and $<12 \%$ by other oxidants), it is clear that that the role of soil matrix as a limiting factor is more prominent for conventional oxidants (Fig. 
$3 \mathrm{~B}$ and 2). In addition to the soil matrix effect, it is also highly probable that there is an effect of $\mathrm{pH}$ since efficiency of ferrate( $\mathrm{VI}$ ) oxidation is better under acidic conditions (i.e. sand slurry $\mathrm{pH} 6$ vs. soil slurry $\mathrm{pH}$ 9.9). However, observed differences in efficiency of conventional oxidants between sand and soil (raw or decarbonated) medium suggest that their poor oxidation efficiency in raw soil is not exclusively associated to the alkaline $\mathrm{pH}$. Rather, it could be associated to the soil matrix effect. The good efficiency in PCBs removal by ferrate( $\mathrm{VI})$ in raw soil $(\mathrm{pH} 9.9)$ as well as in spiked sand $(\mathrm{pH} 6)$ and decarbonated soil highlights its adaptability over a wide range of experimental conditions.

\subsubsection{Availability of PCBs}

To assess whether the availability of PCBs in the soil matrix may impact the ferrate(VI) oxidation, chemical and physical means were employed in order to increase the availability of pollutants before starting $\mathrm{Fe}(\mathrm{VI})$-based oxidation. Use of pollutant-availability enhancement agents such as cyclodextrin or thermal pretreatment by increasing temperature were found to enhance pollutant availability in contaminated soils for subsequent remediation $[1,25,26,30]$. However, in our case, the use of cyclodextrin at $0.05 \mathrm{M}$ or $0.10 \mathrm{M}$ did not impact the subsequent degradation of PCBs (Fig. S8). Similarly, exposing soil to an elevated temperature $\left(40^{\circ} \mathrm{C}\right)$ prior to treatment resulted in negligible increase in subsequent pollutant removal. Thus, these pretreatments did not yield any positive impacts on pollutant unavailability or the subsequent treatment. These observations attest the strong refractory nature of PCBs in tested soil.

Impact of pollutant availability on Fe(VI)-based treatments was assessed by following another strategy which is based on re-spiking the contaminated soil (Fig. 6). For this purpose, EOM extraction procedure (similar to that for spiking on sand) was used (section 
2.3). The removal efficiency of PCBs increased from $30 \%$ (in raw soil) to $42 \%$ in re-spiked soil

(Fig. 6A), suggesting that the availability of PCBs in the soil plays a crucial role on the overall removal performance. Indeed, availability of pollutant increases in spiked soil since it is a freshly contaminated matrix and thus PCBs are less sequestrated than in historically aged contaminated soil [5].

The application of ferrate $(\mathrm{VI}), \mathrm{HSO}_{5}{ }^{-}$and ferrate $(\mathrm{VI}) / \mathrm{HSO}_{5}{ }^{-}$treatments was also tested in spiked soil. Obtained results indicate that $\mathrm{Fe}(\mathrm{VI})$ alone and combined $\mathrm{Fe}(\mathrm{VI}) / \mathrm{HSO}_{5}{ }^{-}$system (Fig. 6B) are the most efficient for the remediation of the soil and both reach degradation efficiency in PCBs around 42\%. On the other hand, $\mathrm{HSO}_{5}^{-}$alone and $\mathrm{Fe}(\mathrm{II}) / \mathrm{H}_{2} \mathrm{O}_{2}$ system are less efficient and remove less than $20 \%$ of PCBs from the soil. This highlights the fact that ferrate(VI) is crucial for the degradation of PCBs through mainly electron transfer process (section 3.1.2). Ferrate(VI) based treatment allowed a good removal of heavy PCBs whereas treatments based on conventional oxidant $\left(\mathrm{HSO}_{5}{ }^{-}\right.$and $\left.\mathrm{Fe}(\mathrm{II}) / \mathrm{H}_{2} \mathrm{O}_{2}\right)$ target preferentially lower chlorinated PCBs (Fig. 6B). Indeed, degradation mechanism using conventional oxidants is mainly based on radical-pathway since aromatic rings of light PCBs are more accessible [1]. In contrast, ferrate(VI) can be more efficient for the removal of heavy PCBs since the mechanism goes mainly through electron transfer and the attack of $\mathrm{e}^{-}$rich moieties such as

\section{$\mathrm{Cl}$ (section 3.1.3).}

\section{Conclusion}

This is the first study to assess the use of Ferrate $(\mathrm{VI})$ for the remediation of PCBs in contaminated soil. Ferrate(VI) was found more efficient (30\% PCB removal) than conventional oxidants $\left(\mathrm{H}_{2} \mathrm{O}_{2}, \mathrm{~S}_{2} \mathrm{O}_{8}{ }^{2-}\right.$ and $\left.\mathrm{HSO}_{5}{ }^{-}\right)(<12 \% \mathrm{PCB}$ removal). However, integrated application of Ferrate( $\mathrm{VI})$ and conventional oxidants further improved the degradation 
efficiency (40\%). In contaminated soil, ferrate(VI) preferentially degraded the heavy PCBs since $\mathrm{Fe}(\mathrm{VI})$ targets preferentially $\mathrm{e}^{-}$rich moieties like $\mathrm{Cl}$. These high chlorinated $\mathrm{PCBs}$ were transformed into lower chlorinated ones. On the other hand, lower efficiency of conventional oxidants can be associated to their poor ability to oxidize the aromatic structure hindered by $\mathrm{Cl}$ substituents. Observed synergy in combined system arises from dual action of $\mathrm{Fe}(\mathrm{VI})$ and conventional oxidants to degrade $\mathrm{PCBs}$ through electron transfer and radical pathway, respectively. Since the identification and quantification of $P C B$ degradation by-products in the soil system is not straightforward, this task could be preliminarily performed in aqueous phase, as recently reported in [32,33], with the aim to better understand the degradation pathways in a more complex system (i.e. soil).

Further experiments revealed that oxidation efficiency is limited by various soil factors like carbonate contents, overall soil matrix and pollutant availability. Effect of these factors was more pronounced for conventional oxidants than ferrate(VI), highlighting its better adaptability for soil application. The assessment of the limiting factors in tested soil with high carbonates content $\left(30 \mathrm{wt} \% \mathrm{CaCO}_{3}\right)$ using ferrate( $\mathrm{VI}$ ) validates the dominant degradation pathway through electron transfer. This is a key point in the relatively success of ferrate over conventional oxidants degrading through radicals. Although the overall removal extent of PCB did not exceed $50 \%$, this pioneered work opens doors to develop ferrate(VI)based approaches for soil remediation.

Ferrate(VI) could find promising applications for remediation of soil with high carbonates content. Indeed, high content of carbonates gives rise to alkaline $\mathrm{pH}$ and affects negatively all the investigated oxidation processes, ferrate(VI) is the only oxidant which exhibited significant PCB removal in such conditions. However, further studies on different 
kinds of soil, nature of pollutants and history of contamination are needed to derive a general conclusion about ferrate(VI) application for soil remediation. As highlighted above, in addition to the removal of $\mathrm{PCBs}$, ferrate(VI) oxidation degraded heavy $\mathrm{PCBs}$ to lower chlorinated ones. Since biodegradability of PCBs increases with decreasing chlorination extent and decomposition by-product of ferrate itself (i.e. Fe $\mathrm{e}^{\text {III }}$-oxides) is not toxic, ferrate(VI) based oxidation could be effectively coupled with bioremediation for higher remediation of PCB contaminated soils. Finally, further studies should be devoted to comprehensively elucidate the ferrate(VI) oxidation mechanism in soil.

\section{Acknowledgement}

Authors wish to acknowledge the French Environment and Energy Management Agency (ADEME) for the financial support ( $\left.\mathrm{N}^{\circ} 1472 \mathrm{C0030}\right)$ and the supply of the aged PCBcontaminated soil. Dr. Usman thanks the Humboldt Foundation, Germany for research fellowship.

\section{References}

[1] V. Rybnikova, M. Usman, K. Hanna, Removal of PCBs in contaminated soils by means of chemical reduction and advanced oxidation processes, Environ. Sci. Pollut. Res. 23(17) (2016) 17035-17048.

[2] H. I. Gomes, C. Dias-Ferreira, A. B. Ribeiro, Overview of in situ and ex situ remediation technologies for PCB-contaminated soils and sediments and obstacles for full-scale application, Sci. Tot. Environ. 445-446 (2013) 237-260. 
[3] G.-D. Fang, D. D. Dionysiou, D.-M. Zhou, Y. Wang, X.-D. Zhu, J.-X. Fan, L. Cang, Y.-J. Wang, Transformation of polychlorinated biphenyls by persulfate at ambient temperature, Chemosphere 90 (2013) 1573-1580.

[4] X. Tang, M. Z. Hashmi, B. Zeng, J. Yang, C. Shen, Application of iron-activated persulfate oxidation for the degradation of PCBs in soil, Chem. Eng. J. 279 (2015) 673-680.

[5] M. Usman, P. Faure, C. Ruby, K. Hanna, Remediation of PAH-contaminated soils by magnetite catalyzed Fenton-like oxidation, Appl. Catal. B 117-118 (2012) 10-17.

[6] M. Feng, L. Cizmas, Z. Wang, V. K. Sharma, Synergistic effect of aqueous removal of fluoroquinolones by a combined use of peroxymonosulfate and ferrate(VI), Chemosphere 177 (2017) 144-148.

[7] Q. Han, H. Wang, W. Dong, T. Liu, Y. Yin, H. Fan, Degradation of bisphenol A by ferrate(VI) oxidation: Kinetics, products and toxicity assessment, Chem. Eng. J. 262 (2015) 34-40.

[8] J. M. Quiroga, A. Riaza, M. A. Manzano, Chemical degradation of PCB in the contaminated soils slurry: Direct Fenton oxidation and desorption combined with the photo-Fenton process, J. Environ. Sci. Heal. A 44 (2009) 1120-1126.

[9] V. K. Sharma, Potassium ferrate(VI): an environmentally friendly oxidant, Adv. Environ. Res. 6 (2002) 143-156.

[10] P. K. Rai, J. Lee, S. K. Kailasa, E. E. Kwon, Y. F. Tsang, Y. S. Ok, K.-H. Kim, A critical review of ferrate(VI)-based remediation of soil and groundwater, Environ. Res. 160 (2018) 420-448.

[11] M. Homolkova, P. Hrabak, M. Kolar, M. Cernik, Degradability of hexachlorocyclohexane in water using ferrate (VI), Water Sci. Technol. 73(3) (2015) 405-411. 
[12] P. Zajicek, M. Kolar, R. Prucek, V. Ranc, P. Bednar, R. S. Varma, V. K. Sharma, R. Zboril,

Oxidative degradation of triazine- and sulfonylurea-based herbicides using Fe(VI): The case study of atrazine and idosulfuron with kinetics and degradation products, Sep. Purif. Technol. 156(3) (2015) 1041-1046.

[13] X. Sun, K. Zu, H. Liang, L. Sun, L. Zhang, C. Wang, V. K. Sharma, Electrochemical synthesis of ferrate(VI) using sponge iron anode and oxidative transformations of antibiotic and pesticide, J. Hazard. Mater. 344 (2018) 1155-1164.

[14] Y. Lee, J. Yoon, U. V. Gunten, Kinetics of the Oxidation of Phenols and Phenolic Endocrine Disruptors during Water Treatment with Ferrate (Fe(VI)), Environ. Sci. Technol. 39 (2005) 8978-8984.

[15] J. Q. Jiang, Research progress in the use of ferrate(VI) for the environmental remediation, J. Hazard. Mater. 146 (2007) 617-623.

[16] M. Homolkova, P. Hrabak, N. Graham, M. Cernik, A study of the reaction of ferrate with pentachlorophenol - kinetics and degradation products, Water Sci. Technol. 75(1-2) (2017) 189-195.

[17] V. K. Sharma, C. R. Burnett, F. J. Millero, Dissociation constants of the monoprotic ferrate(VI) ion in NaCl media, Phys. Chem. Chem. Phys. 3 (2001) 2059-2062.

[18] K. Manoli, G. Nakhla, A. K. Ray, V. K. Sharma, Enhanced oxidative transformation of organic contaminants by activation of ferrate(VI) : Possible involvement of FeV/FelV species, Chem. Eng. J. 307 (2017) 513-517.

[19] J.-Q. Jiang, The role of ferrate(VI) in the remediation of emerging micro pollutants, Procedia Environ. Sci. 18 (2013) 418-426. 
[20] A. Talaiekhozani, M. R. Talaei, S. Rezania, An overview on production and application of ferrate (VI) for chemical oxidation, coagulation and disinfection of water and wastewater, J. Environ. Chem. Eng. 5 (2017) 1828-1842.

[21] C. Wang, N. Klamerth, R. Huang, H. Elnakar, M. G. El-Din, Oxidation of Oil Sands ProcessAffected Water by Potassium Ferrate(VI), Environ. Sci. Technol. 50 (2016) 4238-4247.

[22] S. Sun, S. Pang, J. Jiang, J. Ma, Z. Huang, J. Zhang, Y. Liu, C. Xu, Q. Liu, Y. Yuan, The combination of ferrate( $\mathrm{VI})$ and sulfite as a novel advanced oxidation process for enhanced degradation of organic contaminants, Chem. Eng. J. 333 (2018) 11-19.

[23] Z. Zhou, J.-Q. Jiang, Treatment of selected pharmaceuticals by ferrate(VI): Performance, kinetic studies and identification of oxidation products, J. Pharmaceut. Biomed. 106 (2015) $37-45$.

[24] V. K. Sharma, Ferrate(VI) and ferrate(V) oxidation of organic compounds: Kinetics and mechanism, Coord. Chem. Rev. 257 (2013) 495-510.

[25] C. Viglianti, K. Hanna, C. de Brauera, P. Germain, Removal of polycyclic aromatic hydrocarbons from aged-contaminated soil using cyclodextrins: experimental study, Environ. Poll. 140 (2006) 427-435.

[26] R. H. Kadlec, K. R. Reddy, Temperature effects in treatment wetlands, Water Environ. Res. 73(5) (2001) 543-557.

[27] V. K. Sharma, R. Zboril, R. S. Varma, Ferrates: Greener Oxidants with multimodal Action in Water treatment Technologies, Acc. Chem. Res. 48 (2015) 182-191. 
[28] F. J. Rivas, Polycyclic aromatic hydrocarbons sorbed on soil: a short review of chemical oxidation based treatments, J. Hazard. Mater. 138 (2006) 234-251.

[29] J. Lemaire, M. Bues, T. Kabeche, K. Hanna, M. O. Simonnot, Oxidant selection to treat an aged PAH contaminated soil by in situ chemical oxidation, J. Environ. Chem. Eng. 1 (2013) 1261-1268.

[30] M. Usman, A. Chaudhary, C. Biache, P. Faure, K. Hanna, Effect of thermal pre-treatment on the availability of PAHs for successive chemical oxidation in contaminated soils, Environ. Sci. Pollut. Res. 23 (2016) 1371-1380.

[31] M. Usman, J. M. Byrne, A. Chaudhary, S. Orsetti, K. Hanna, C. Ruby, A. Kappler, S. B. Haderlein, Magnetite and Green Rust: Synthesis, Properties, and Environmental Applications of Mixed-Valent Iron Minerals, Chem. Rev. 118(7) (2018) 3251-3304.

[32] W. Qin, G. Fang, Y. Wang, D. Zhou, Mechanistic understanding of polychlorinated biphenyls degradation by peroxymonosulfate activated with CuFe2O4 nanoparticles: Key role of superoxide radicals, Chem. Eng. J. 348 (2018) 526-534.

[33] M. Ahmad, M. A. Simon, A. Sherrin, M. E. Tuccillo, J. L. Ullman, A. L. Teel, R. J. Watts, Treatment of polychlorinated biphenyls in two surface soils using catalyzed $\mathrm{H} 2 \mathrm{O} 2$ propagations, Chemosphere 84(7) (2011) 855-862.

[34] V. Flotron, C. Delteil, Y. Padellec, V. Camel, Removal of sorbed polycyclic aromatic hydrocarbons from soil, sludge and sediment samples using the Fenton's reagent process, Chemosphere 59 (2005) 1427-1437.

[35] M. Kolar, P. Novak, K. M. Siskova, L. Machala, O. Malina, J. Tucek, V. K. Sharma, R. Zboril, Impact of inorganic buffering ions on the stability of $\mathrm{Fe}(\mathrm{VI})$ in aqueous solution: Role of carbonate ion, Phys. Chem. Chem. Phys. 18 (2016) 4415-4422. 
[36] M. Feng, V. K. Sharma, Enhanced oxidation of antibiotics by ferrate(VI)-sulfur(IV) system: Elucidating multi-oxidant mechanism, Chem. Eng. J. 341 (2018) 137-145. 
Table 1. Physico-chemical properties of aged PCB-contaminated soil

\begin{tabular}{|c|c|c|}
\hline Parameter & Value & Unit \\
\hline \multicolumn{3}{|c|}{ Soil texture } \\
\hline Soil organic matter (SOM) & 18.4 & $\mathrm{~g} / \mathrm{Kg}$ \\
\hline $\mathrm{CaCO}_{3}$ & 294 & $\mathrm{~g} / \mathrm{Kg}$ \\
\hline $\mathrm{pH}$ (in water) & 9.93 & \\
\hline \multicolumn{3}{|c|}{ Elemental composition } \\
\hline Aluminium (Al) & 0.068 & $\mathrm{~g} / 100 \mathrm{~g}$ \\
\hline Silicon (Si) & 0.042 & $\mathrm{~g} / 100 \mathrm{~g}$ \\
\hline Iron (Fe) & 0.216 & $\mathrm{~g} / 100 \mathrm{~g}$ \\
\hline Chromium ( & 69.5 & $\mathrm{mg} / \mathrm{Kg}$ \\
\hline Copper (Cu) & 23.2 & $\mathrm{mg} / \mathrm{Kg}$ \\
\hline Nickel (Ni) & 39.5 & $\mathrm{mg} / \mathrm{Kg}$ \\
\hline Zinc (Zn) & 70.5 & $\mathrm{mg} / \mathrm{Kg}$ \\
\hline Cobalt (Co) & 9.83 & $\mathrm{mg} / \mathrm{Kg}$ \\
\hline Lead $(\mathrm{Pb})$ & 15.2 & $\mathrm{mg} / \mathrm{Kg}$ \\
\hline Cadmium (Cd) & 0.152 & $\mathrm{mg} / \mathrm{Kg}$ \\
\hline Thallium (TI) & 0.603 & $\mathrm{mg} / \mathrm{Kg}$ \\
\hline Molybdenium (Mo) & 0.670 & $\mathrm{mg} / \mathrm{Kg}$ \\
\hline
\end{tabular}


Table 2. Concentration of the main PCBs in the soil fraction of $500 \mu \mathrm{m}$

\begin{tabular}{|c|c|c|}
\hline PCB congener & Degree of chlorination & Concentration [ppm] \\
\hline 28 & tri-CB & 1.72 \\
\hline 52 & tetra-CB & 39.83 \\
\hline 101 & penta-CB & 143.51 \\
\hline 118 & penta-CB & 43.37 \\
\hline 138 & hexa-CB & 197.23 \\
\hline 153 & hexa-CB & 188.43 \\
\hline 180 & hepta-CB & 164.33 \\
\hline 33 & tri-CB & 0.16 \\
\hline 53 & tetra-CB & 0.43 \\
\hline 5 & penta-CB & 12.31 \\
\hline 110 & penta-CB & 55.61 \\
\hline 149 & hexa-CB & 101.15 \\
\hline 156 & hexa-CB & 11.18 \\
\hline 167 & hexa-CB & 12.84 \\
\hline 170 & hepta-CB & 46.58 \\
\hline TOTAL & & 1018.68 \\
\hline
\end{tabular}


Table 3. Summary of experimental conditions

\begin{tabular}{|c|c|c|c|c|}
\hline \multicolumn{2}{|l|}{ Experiment } & $\begin{array}{l}\text { Ferrate } \\
\text { loading }\end{array}$ & $\begin{array}{l}\text { Concentration } \\
\text { of oxidant }\end{array}$ & L/S ratio \\
\hline \multirow{4}{*}{\multicolumn{2}{|c|}{ Effect of liquid-to-solid ratio }} & $0.5 \mathrm{~g} / \mathrm{g}$ & - & 1 \\
\hline & & $0.5 \mathrm{~g} / \mathrm{g}$ & - & 5 \\
\hline & & $0.5 \mathrm{~g} / \mathrm{g}$ & - & 10 \\
\hline & & $0.5 \mathrm{~g} / \mathrm{g}$ & - & 15 \\
\hline \multirow{6}{*}{$\begin{array}{l}\text { Ferrate dose (single and sequential } \\
\text { additions) }\end{array}$} & $0.25 \mathrm{~g} / \mathrm{g}$ in $24 \mathrm{~h}$ & $0.25 \mathrm{~g} / \mathrm{g}$ & - & 1 \\
\hline & $0.5 \mathrm{~g} / \mathrm{g}$ in $24 \mathrm{~h}$ & $0.5 \mathrm{~g} / \mathrm{g}$ & - & 1 \\
\hline & $0.5 \mathrm{~g} / \mathrm{g}$ in $48 \mathrm{~h}$ & $0.5 \mathrm{~g} / \mathrm{g}$ & - & 1 \\
\hline & $2 \times 0.25 \mathrm{~g} / \mathrm{g}$ in $24 \mathrm{~h}$ & $0.5 \mathrm{~g} / \mathrm{g}$ & - & 1 \\
\hline & $2 \times 0.5 \mathrm{~g} / \mathrm{g}$ in $48 \mathrm{~h}$ & $1 \mathrm{~g} / \mathrm{g}$ & - & 1 \\
\hline & $4 \times 0.25 \mathrm{~g} / \mathrm{g}$ in $48 \mathrm{~h}$ & $1 \mathrm{~g} / \mathrm{g}$ & - & 1 \\
\hline \multirow{6}{*}{ Comparison of oxidation treatments } & Ferrate(VI) & $0.5 \mathrm{~g} / \mathrm{g}$ & - & 1 \\
\hline & $\mathrm{HSO}_{5}^{-}$ & - & $0.2 \mathrm{M}$ & 1 \\
\hline & & $0.5 \mathrm{~g} / \mathrm{g}$ & $2 \mathrm{mM}$ & 1 \\
\hline & & $0.5 \mathrm{~g} / \mathrm{g}$ & $20 \mathrm{mM}$ & 1 \\
\hline & & $0.5 \mathrm{~g} / \mathrm{g}$ & $0.2 \mathrm{M}$ & 1 \\
\hline & $\mathrm{S}_{2} \mathrm{O}_{8}{ }^{2-}$ & - & $0.2 \mathrm{M}$ & 1 \\
\hline
\end{tabular}




\begin{tabular}{|c|c|c|c|c|c|}
\hline & & & $0.5 \mathrm{~g} / \mathrm{g}$ & $2 \mathrm{mM}$ & 1 \\
\hline & & & $0.5 \mathrm{~g} / \mathrm{g}$ & $20 \mathrm{mM}$ & 1 \\
\hline & & & $0.5 \mathrm{~g} / \mathrm{g}$ & $0.2 \mathrm{M}$ & 1 \\
\hline & $\mathrm{Fe}(\mathrm{II}) / \mathrm{H}_{2} \mathrm{O}_{2}$ & & - & $2 \% \mathrm{H}_{2} \mathrm{O}_{2}$ & 1 \\
\hline & & & $0.1 \mathrm{~g} / \mathrm{g} \mathrm{FeSO}_{4}$ & $10 \% \mathrm{H}_{2} \mathrm{O}_{2}$ & 1 \\
\hline & & & $0.1 \mathrm{~g} / \mathrm{g} \mathrm{FeSO}_{4}$ & $5 \% \mathrm{H}_{2} \mathrm{O}_{2}$ & 1 \\
\hline & & & $0.1 \mathrm{~g} / \mathrm{g} \mathrm{FeSO}_{4}$ & $2 \% \mathrm{H}_{2} \mathrm{O}_{2}$ & 1 \\
\hline Effects of soil matrix & Decarbonatec & soil & $0.5 \mathrm{~g} / \mathrm{g}$ & - & 1 \\
\hline & & & - & $0.2 \mathrm{M} \mathrm{HSO}_{5}^{-}$ & 1 \\
\hline & & & $0.5 \mathrm{~g} / \mathrm{g}$ & $0.2 \mathrm{M} \mathrm{HSO}_{5}^{-}$ & 1 \\
\hline & & & - & $0.2 \mathrm{M} \mathrm{S}_{2} \mathrm{O}_{8}{ }^{2-}$ & 1 \\
\hline & & & $0.5 \mathrm{~g} / \mathrm{g}$ & $0.2 \mathrm{M} \mathrm{S}_{2} \mathrm{O}_{8}{ }^{2-}$ & 1 \\
\hline & & & - & $2 \% \mathrm{H}_{2} \mathrm{O}_{2}$ & 1 \\
\hline & & & $0.1 \mathrm{~g} / \mathrm{g} \mathrm{FeSO}_{4}$ & $2 \% \mathrm{H}_{2} \mathrm{O}_{2}$ & 1 \\
\hline & Spiked sand & & $0.5 \mathrm{~g} / \mathrm{g}$ & - & 1 \\
\hline & & & $0.5 \mathrm{~g} / \mathrm{g}$ & $0.2 \mathrm{M} \mathrm{HSO}_{5}^{-}$ & 1 \\
\hline & & & $0.1 \mathrm{~g} / \mathrm{g} \mathrm{FeSO}_{4}$ & $2 \% \mathrm{H}_{2} \mathrm{O}_{2}$ & 1 \\
\hline Availability of PCBs & Cyclodextrin & $0.05 \mathrm{M}$ & $0.5 \mathrm{~g} / \mathrm{g}$ & - & 1 \\
\hline & & $0.1 \mathrm{M}$ & $0.5 \mathrm{~g} / \mathrm{g}$ & - & 1 \\
\hline & Temperature & $\left.40^{\circ} \mathrm{C}\right)$ & $0.5 \mathrm{~g} / \mathrm{g}$ & - & 1 \\
\hline
\end{tabular}




\begin{tabular}{|l|l|l|l|l|}
\hline \multirow{2}{*}{} & Spiked soil & $0.5 \mathrm{~g} / \mathrm{g}$ & - & 1 \\
\cline { 3 - 5 } & & $0.5 \mathrm{~g} / \mathrm{g}$ & $0.2 \mathrm{M} \mathrm{HSO}_{5}^{-}$ & 1 \\
\cline { 3 - 5 } & & & & \\
\cline { 3 - 5 } & & $0.1 \mathrm{~g} / \mathrm{g} \mathrm{FeSO}_{4}$ & $2 \% \mathrm{H}_{2} \mathrm{O}_{2}$ & 1 \\
\hline
\end{tabular}


Figure 1. Degradation extent of different $\mathrm{PCBs}$ in aged soil using $0.5 \mathrm{~g} / \mathrm{g}$ of ferrate $(\mathrm{VI})$ at $\mathrm{L} / \mathrm{S}=$ 1 after 24 hours. $C_{0}$ represents the initial concentration of the assigned PCB in untreated soil while $C$ represents the concentration of $\mathrm{PCBs}$ after ferrate(VI) oxidation treatment.
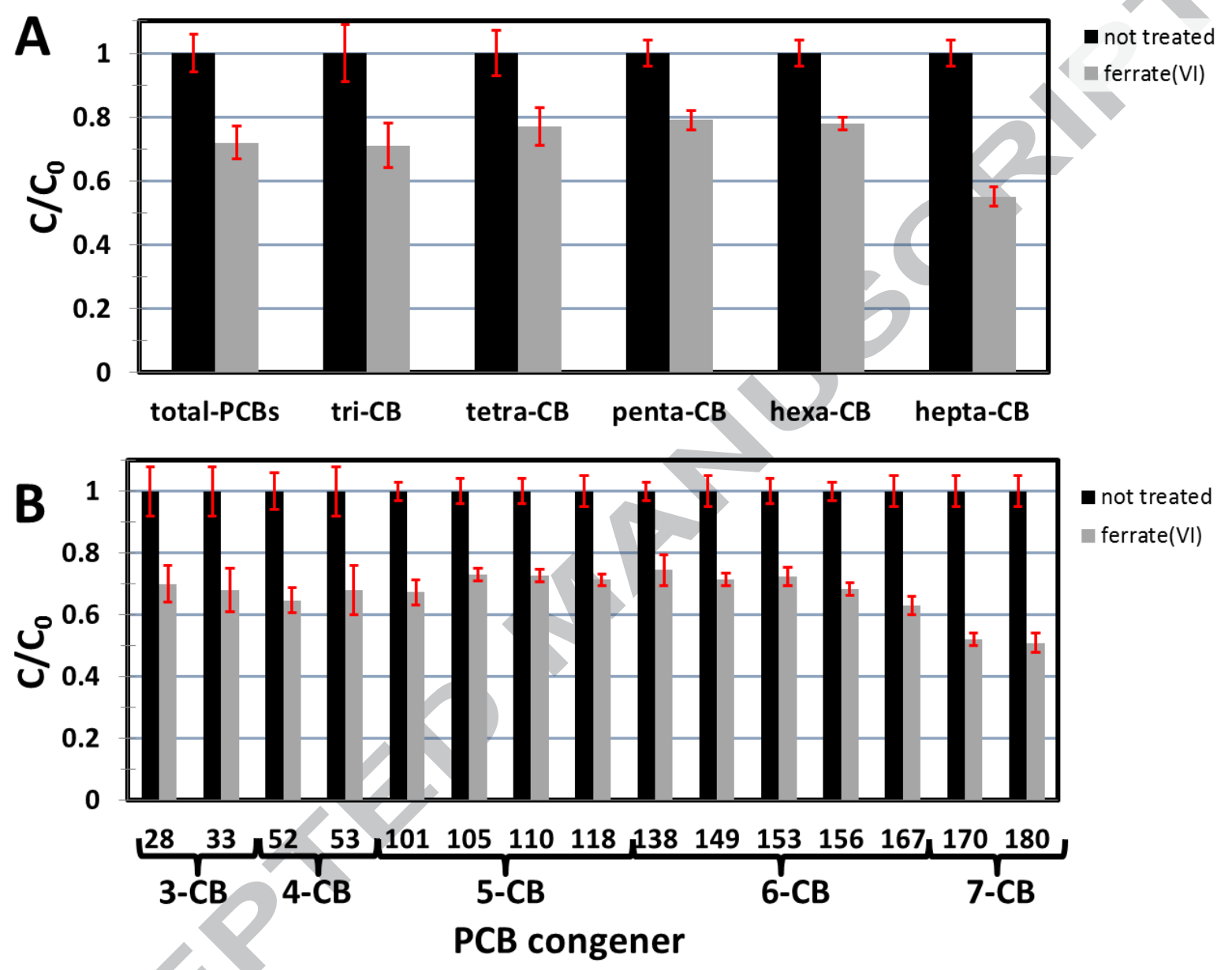
Figure 2. Remediation of PCBs-contaminated soil using Fe(VI), conventional oxidants and integrated use of ferrate( $\mathrm{VI}$ ) with $\mathrm{HSO}_{5}{ }^{-}$and $\mathrm{S}_{2} \mathrm{O}_{8}{ }^{2-}$. Each oxidation process lasts 24 hours at $\mathrm{L} / \mathrm{S}=1$ while the dose of ferrate $(\mathrm{VI})$ and iron(II) is $0.5 \mathrm{~g} / \mathrm{g}$ and $0.1 \mathrm{~g} / \mathrm{g}$, respectively. The concentration in $\mathrm{HSO}_{5}{ }^{-}, \mathrm{S}_{2} \mathrm{O}_{8}{ }^{2-}$ and $\mathrm{H}_{2} \mathrm{O}_{2}$ is $0.2 \mathrm{M}, 0.2 \mathrm{M}$ and 2 wt\%, respectively. $\mathrm{C}_{0}$ represents the initial concentration of the total PCBs in untreated soil while $C$ represents the concentration of PCBs different single and combined oxidation treatments.

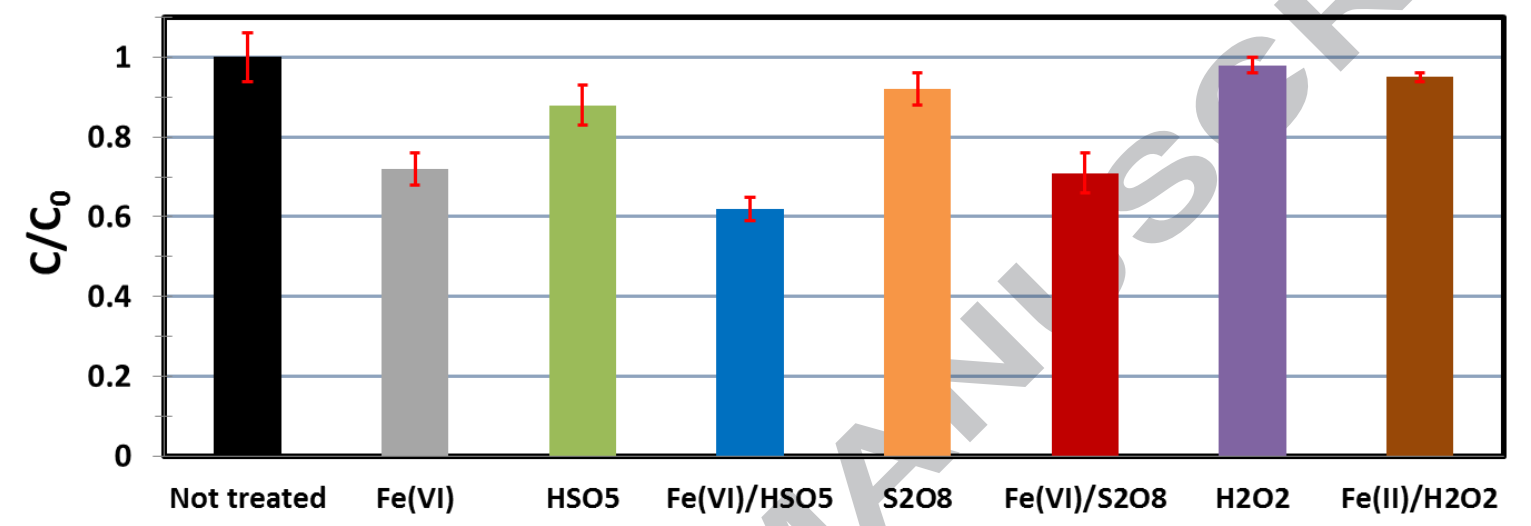


Figure 3. Effect of (A) ferrate(VI) oxidation and (B) integrated application of $\mathrm{Fe}(\mathrm{VI})$ with $\mathrm{HSO}_{5}{ }^{-}$ on PCB removal in both raw and spiked sand. Each oxidation process is 24 hours long and L/S $=1$. The dose of $\mathrm{Fe}(\mathrm{VI})$ and $\mathrm{HSO}_{5}{ }^{-}$is $0.5 \mathrm{~g} / \mathrm{g}$ and $0.2 \mathrm{M}$, respectively. In $\mathrm{Fe}(\mathrm{II})$-activated $\mathrm{H}_{2} \mathrm{O}_{2}$ experiment, $0.1 \mathrm{~g} / \mathrm{g}$ of iron(II) is used with $2 w t \% \mathrm{H}_{2} \mathrm{O}_{2}$. $\mathrm{C}_{0}$ represents the initial concentration of the assigned PCB in untreated soil while $C$ represents the concentration of PCBs after different oxidation treatments.

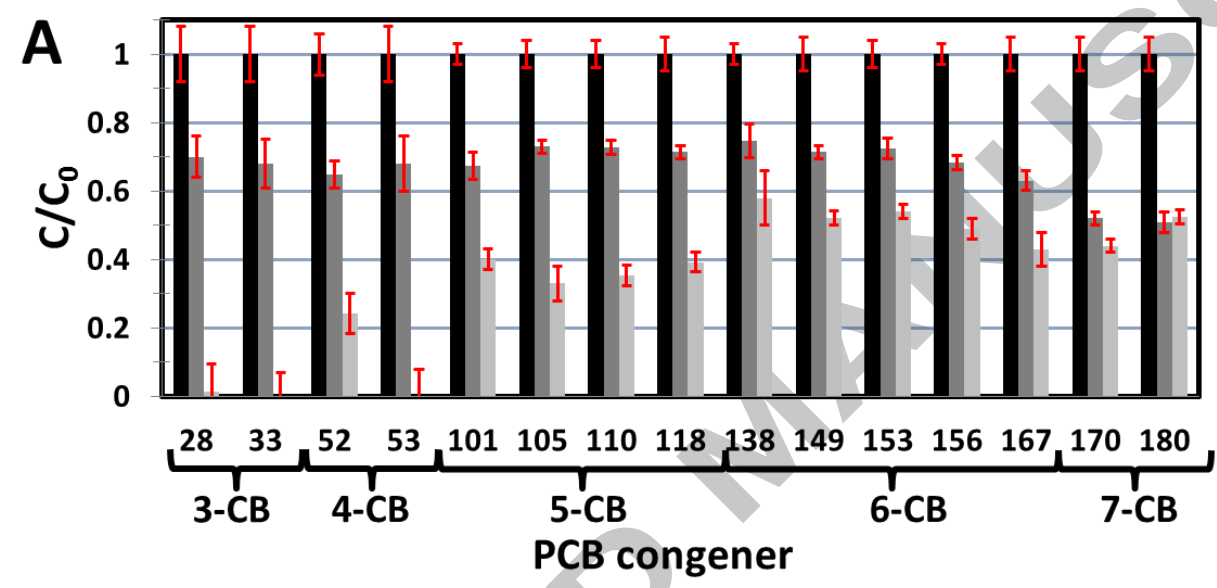

not treated

raw soil

spiked sand

B

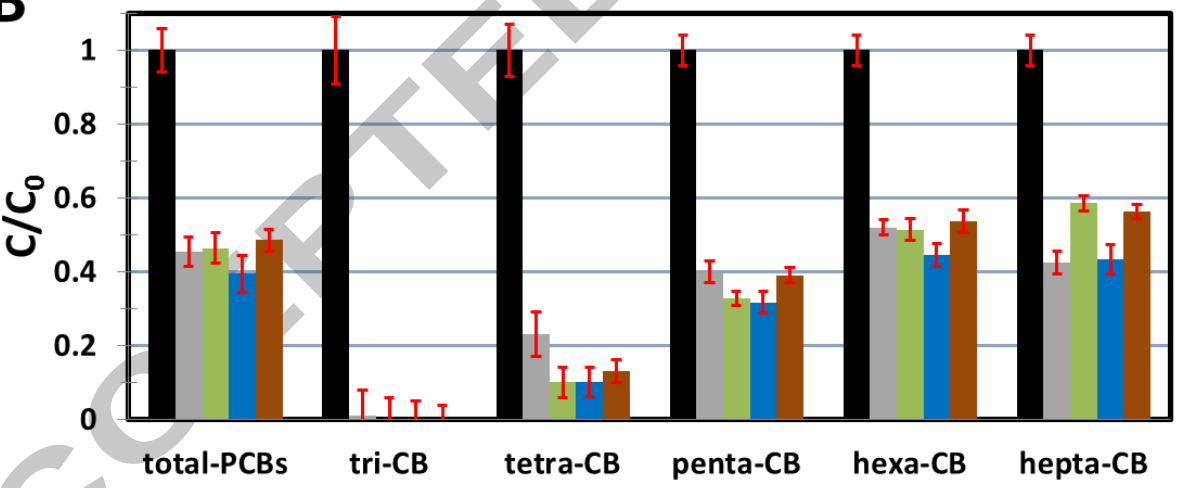

spiked sand

not treated

$\because \mathrm{Fe}(\mathrm{VI})$

- $\mathrm{HSO}$

$\square \mathrm{Fe}(\mathrm{VI}) / \mathrm{HSO} 5$

a $\mathrm{Fe}(\mathrm{II}) / \mathrm{H} 2 \mathrm{O} 2$ 
Figure 4. Degradation rate of $(A)$ different $P C B$ groups and $(B)$ particular $P C B$ s in both raw and decarbonated soils using ferrate(VI) oxidation. In each experiment, the reaction time is set at $24 \mathrm{~h}, \mathrm{~L} / \mathrm{S}=1$ and the dose of $\mathrm{Fe}(\mathrm{VI})$ is $0.5 \mathrm{~g} / \mathrm{g}$. $C_{0}$ represents the initial concentration of the assigned PCB in untreated soil while $C$ represents the concentration of PCBs after ferrate(VI) oxidation treatment.
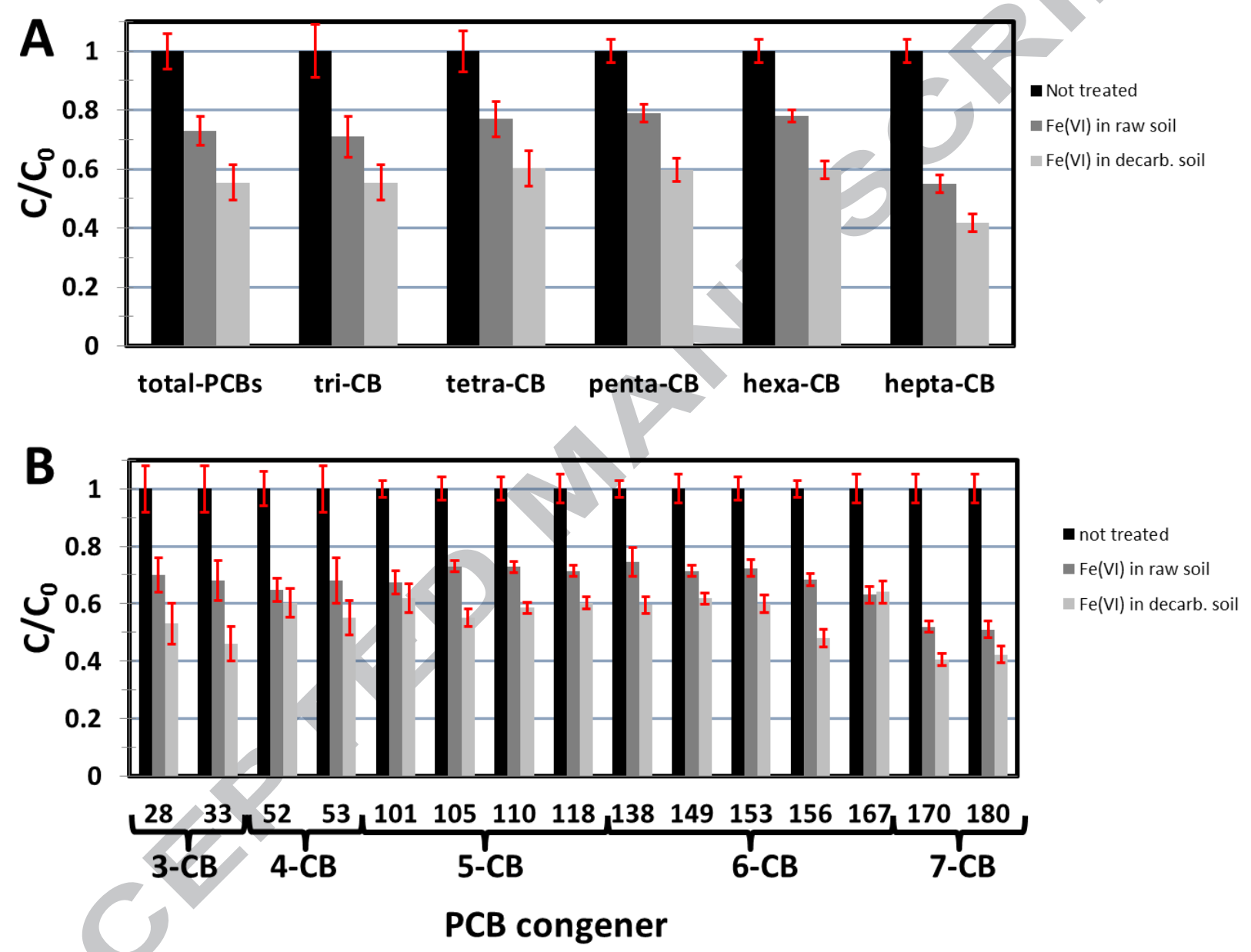
Figure 5. Degradation of PCBs on decarbonated soil using Fe(VI), conventional oxidants and integrated use of $\mathrm{Fe}(\mathrm{VI})$ with $\mathrm{HSO}_{5}{ }^{-}$and $\mathrm{S}_{2} \mathrm{O}_{8}{ }^{2-}$. Each oxidation process lasts 24 hours at $\mathrm{L} / \mathrm{S}=$ 1 while the dose of ferrate(VI) and iron(II) is $0.5 \mathrm{~g} / \mathrm{g}$ and $0.1 \mathrm{~g} / \mathrm{g}$, respectively. The concentration in $\mathrm{HSO}_{5}{ }^{-}, \mathrm{S}_{2} \mathrm{O}_{8}{ }^{2-}$ and $\mathrm{H}_{2} \mathrm{O}_{2}$ is $0.2 \mathrm{M}, 0.2 \mathrm{M}$ and 2 wt\%, respectively. $\mathrm{C}_{0}$ represents the initial concentration of the total PCBs in untreated soil while $C$ represents the concentration of PCBs different single and combined oxidation treatments.

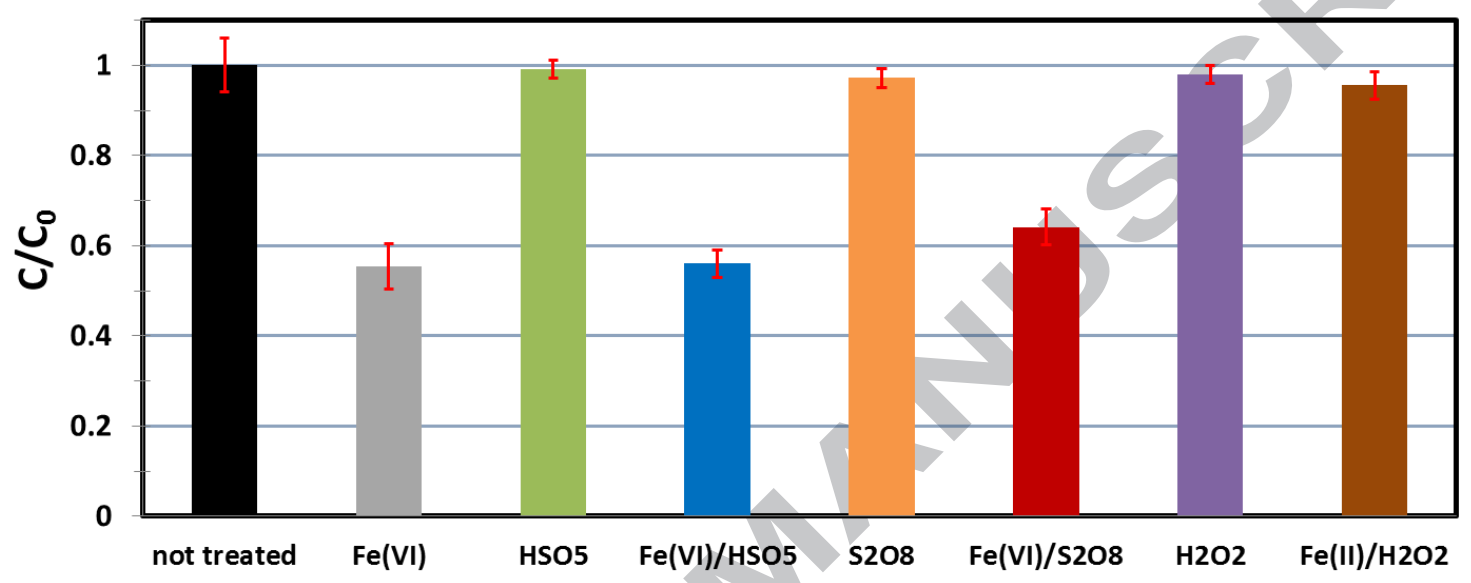


Figure 6. Effect of (A) ferrate(VI) oxidation and (B) integrated application of $\mathrm{Fe}(\mathrm{VI})$ with $\mathrm{HSO}_{5}{ }^{-}$ on PCB removal in both raw and spiked soils. Each oxidation process is 24 hours long and L/S $=1$. The dose of $\mathrm{Fe}(\mathrm{VI})$ and $\mathrm{HSO}_{5}{ }^{-}$is $0.5 \mathrm{~g} / \mathrm{g}$ and $0.2 \mathrm{M}$, respectively. In $\mathrm{Fe}(\mathrm{II})$-activated $\mathrm{H}_{2} \mathrm{O}_{2}$ experiment, $0.1 \mathrm{~g} / \mathrm{g}$ of iron(II) is used with $2 w t \% \mathrm{H}_{2} \mathrm{O}_{2}$. $\mathrm{C}_{0}$ represents the initial concentration of the assigned PCB in untreated soil while $C$ represents the concentration of PCBs after different oxidation treatments.
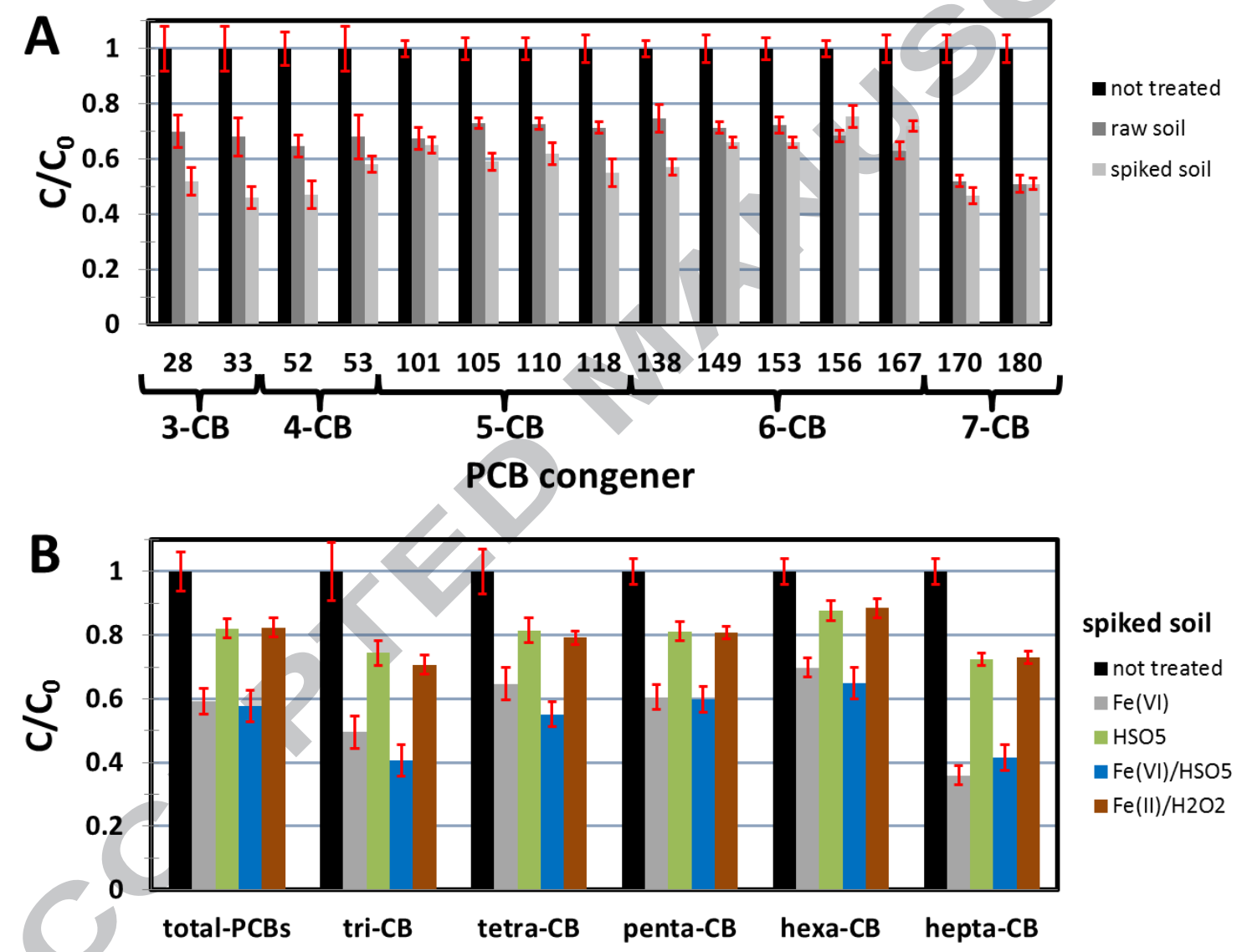


\section{Highlights}

- $\mathrm{Fe}(\mathrm{VI})$ oxidant is more efficient than conventional oxidants in PCBs removal.

- Combined $\mathrm{Fe}(\mathrm{VI}) / \mathrm{HSO}_{5}{ }^{-}$treatment can remove approximatively $40 \%$ of PCBs.

- High carbonates content negatively affects the action of Fe(VI) oxidation.

- The soil matrix has a strong impact on efficiency of ferrate(VI) oxidation. 